\title{
A Case Study of Corpus-Based Materials Developing Stages for Medical Students
}

\author{
Junwei Niu \\ The School of Medical Humanities, Xinxiang Medical University, Xinxiang, Henan Province, China.
}

How to cite this paper: Junwei Niu. (2021) A Case Study of Corpus-Based Materials Developing Stages for Medical Students. Journal of Humanities, Arts and Social Science, 5(2), 204-215.

DOI: 10.26855/jhass.2021.07.004

Received: July 14, 2021

Accepted: August 10, 2021

Published: August 24, 2021

"Corresponding author: Junwei Niu, The School of Medical Humanities, Xinxiang Medical University, Xinxiang, Henan Province, China.

Email: 122502323@qq.com

\begin{abstract}
This case study has reported the corpus-based materials development research and argued that the Corpus-Based materials developing stages deserved more attention in the whole process of teaching and learning. The empirical research was conducted with four teachers and 180 third-year medical students. The participants' comments regarding the functions of corpus-based supplementary materials and activities as a supplement in learning the ESP language skills were analyzed and juxtaposed with the observation data for participants. The significance of this study are multi-aspects: Enriching medical teaching materials; promoting participants' teaching and learning efficiency, quality, and enhancing the relationship between teachers and students; as well as diversifying the Medical English pedagogy. Results indicated that a well-arranged, concise, and convenient Corpus-Based English Supplement (ECBES) is very useful for both teachers and students. They had benefitted from the pedagogical implications of using the ECBES in-class and in their daily learning life.
\end{abstract}

\section{Keywords}

Enriched Corpus-Based English Supplement (ECBES), Materials development, Materials developing stages, Corpus-based materials, Medical students

\section{Introduction}

Materials development is a field of study as well as a practical undertaking. As a field, it studies "the principles and procedures of the design, implementation, and evaluation of language teaching materials". As a practical undertaking, it includes anything that "supplies information about and/or experience of the language in ways designed to promote language learning” (Tomlinson, 2011b, p. 2).

"Why use materials?" This question is the real research gap in the use of materials, which has vital implications in materials development (Graves, 2019, p. 338). Many studies (Bale, 2013; John David Bunting, 2013; Chai, Wannaruk, \& Lian, 2015; Cheung, 2014; Edwin Ko, 2016; Flowerdew, 2015; Storjohann, 2005; Yang, 2014) were concerned about the investigation of corpus-based pedagogy in the Second Language (L2) acquisition and ESP context. However, there is less investigation of EFL and ESP teaching of Corpus-Based Approach (CBA). Brian Paltridge and Sue Starfield (2017) have discussed the relationship between corpus-based and ESP. They indicated that "corpus-based studies have helped us to better understand the nature of specific purpose language use by virtue of the sheer sweep and scale with which this kind of research can now be carried out” (Paltridge \& Starfield, 2017, p. 57). In recent years, many corpora such as the Michigan Corpus of Academic Spoken English (MICASE), the British Academic Spoken English (BASE) corpus and the British Academic Written English (BAWE) corpus had been developed, which have "greatly facilitated" ESP classroom-based research (Paltridge \& Starfield, 2012; Starfield, 2014, p. 9). From pedagogy and Corpus Linguistics (CL) aspects, an Enriched Corpus-Based English Supplement 
(ECBES) has gradually become an active study focus. So, developing a proper supplement in the process of lesson preparation is necessary for teachers to better develop relevant strategies of corpus-based teaching. Meanwhile, the ECBES is especially crucial for the medical students to understand ME meanings, the confusing-concepts-clarifications, as well as the relevance of lesson learning.

According to Brian Tomlinson, the generalized definition of 'materials' is "anything which can be used to facilitate the learning of a language" (Tomlinson, 2003b, p. 2). He avers that materials development is "a field of study" and "a practical undertaking” (Tomlinson, 2003b, p. 1). The significance of ECBES for materials development also includes those two interactive aspects: (1) The designing, implementing, evaluating and recommending of the ECBES, all focus on the field of developing principles and procedures of corpus-based materials. (2) The analysis, production and revision of the ECBES (for example, a booklet or online delivery materials by WeChat or QQ Apps) are the co-work of participant teachers and their third-year medical students, which is an authentic and practical undertaking. In the process of ECBES practice, issues such as 'how should the ECBES developed and evaluated', or 'how should the corpus-based texts be authentic' could be put and solved, which is a benefit to the corpus-based supplementary materials development.

\section{Literature Review}

The earlier researches of materials development were focused on cultural variations, functional learning or sexism topic in the process of preparing the TESOL (teaching English to Speakers of Other Languages) materials. Maurice Imhoof (1968) thought that in the process of teaching materials preparation, cultural variations should be controlled. James Fox (1978) indicated that in the 1970s there were only a few functional classroom materials. He made a function-based module for teaching the telephone English, which was a program of language training for the Canadian Government. The research revealed that it was important to focus on the functional techniques in developing the functional learning materials. At the same time, there was a research which revealed that the biased stereotypical roles of women, were less than those of men in the analyzing linguistic patterns of ESL (English as a Second Language) materials (Hartman \& Judd, 1978). The research suggested that some changes could be done to reduce the use of biased linguistic patterns in ESL materials development, especially for the non-English speakers' language training.

Rebecca Ullmann (1990) thought that the process of developing language teaching materials was a professional development process. In this process, the teachers' ability of "self-direction" could be improved by actively participating in "a wide array of viewpoints" (Ullmann, 1990, p. 714). Meanwhile, there was another direction of professional materials development-CALL (Computer Assisted Language Learning) materials. Michael Levy (1994) reported a survey of CALL materials development forum. In the forum, materials writers' conceptualization and research approaches in developing CALL materials had been surveyed. Their philosophies in teaching and learning were the key factors in developing their own CALL materials.

In 2003, a book—Developing Materials for Language Teaching had been edited by Brian Tomlinson. In this book, several topics, such as materials developing theories, developing circle, principled frameworks, simulations, teacher training, as well as product and process implications had been discussed professionally. The corpus-informed materials could be developed by inspired teachers, who could enrich related materials for "actual learners" (Tomlinson, 2003b, p. 5) in their classrooms (Tomlinson, 2003d). Some topics such as 'learning or acquisition of the materials', 'materials driven by practice or theory' had been discussed. As a complex process, materials development related to syllabus, teachers' and learners' roles, and instructional functions (Wala, 2003). Principled frameworks could be developed by a form of simulations (Tomlinson, 2003a; Tomlinson \& Masuhara, 2003). Text books published by institutions could be seen as both a process and product of changes reflecting on the English Language Teaching (ELT) (Canniveng \& Martinez, 2003; Lyons, 2003).

The book—Research for Materials Development in Language Learning: Evidence for Best Practice was published by Bloomsbury Academic in 2010. The editors were Brian Tomlinson and Hitomi Masuhara. The book presented 23 related reports, which covered 15 countries and 5 continents (Masuhara \& Tomlinson, 2010). Firstly, it pointed out that a few researchers focused on the field of materials evaluation (Tomlinson \& Masuhara, 2010). Then it demonstrated teachers' adaptation effects with intercultural competence (Troncoso, 2010). Soufiane Trabelsi (2010) explained as to how to develop and trial authentic materials for Business English students at a Tunisian University. Several focused topics such as 'evaluating in-house materials or collaborative materials', 'employability training materials', 'L2 songwriting materials', and 'instructional materials' (Al-Busaidi \& Tindle, 2010; Cullen, 2010; Hann, 2010; Pryor, 2010; Stillwell, Kidd et al., 2010). Freda Mishan (Mishan, 2010) suggested to focus on the washback of 
the language teaching and treat correctly the positive and negative effects of materials development. Co-work of developing classroom materials had been displayed by a collaborative approach (Stillwell, McMillan, Gillies, \& Waller, 2010).

Hayo Reinders focused on improving the students' autonomy in selecting, enriching and implementing materials, especially in the preparation of out-of-class teaching (Reinders, 2011). Brian Tomlinson also emphasised electronic delivery of the production of learning materials (Tomlinson, 2012).

In 2013, Brian Tomlinson had edited another important book-Applied Linguistics and Materials Development. In this book, he discussed the close relation of classroom observation and Second language acquisition (SLA) in the scope of materials development as an essential resource (Tomlinson, 2013a; Tomlinson, 2013c). There were other focuses such as 'foreign language learning', 'spoken language teaching and academic literature listening and writing', 'language policy implementing', 'young learners practice', and 'discourse analysis in materials designing' in this book (Ableeva \& Stranks, 2013; Burns \& Hill, 2013; Fenton-Smith, 2013; Ghosn, 2013; Kennedy \& Tomlinson, 2013; Lutzker, 2013; Timmis, 2013). It also reported materials' features in language test washback, which were large-scale, high-stakes, standardized tests and the published materials available (Bailey \& Masuhara, 2013). Brian Tomlinson indicated that several issues and guide of innovation were useful in TESOL and materials development (Tomlinson, 2013b).

In the field of Second Language Acquisition (SLA), the book of SLA Research and Materials Development for Language Learning had been edited by Brian Tomlinson in 2016. In this book he has claimed that materials development was matched and driven by SLA theories (Tomlinson, 2016a; Tomlinson, 2016c). From a view of interdisciplinary, Hitomi Masuhara (2016) relates the language learning materials development to brain researches. The book also presents materials evaluation in 'mobile language learning', 'selection of vocabulary exercises or work plans', 'comprehensibility and cognitive challenge', 'interaction to principled materials in action', and 'Corpus-based materials development' (Bardovi-Harlig \& Mossman, 2016; Darici \& Tomlinson, 2016; Ellis, 2016; Mackey, Ziegler, \& Bryfonski, 2016; Mishan, 2016; Nakata \& Webb, 2016; Reinders \& Pegrum, 2016). As to targeting the importance of materials development, it could be seen as a learning method in both theoretical and practical aspects (Tomlinson, 2016b). In another book, Joan Kang Shin (2016) has suggested building a sustainable community for online TESOL (Teaching English to Speakers of Other Languages) professional development, which was meaningful to the teachers' Continuing Professional Development (CPD). It was also a framework of online materials teaching and learning platform.

Nick Andon (2018) reviewed the Edinburgh Textbooks in TESOL series—Materials development for TESOL and thought that it was useful for users to mediate between theory and practice. John Bunting (2018) listed the essential factors such as components, sources, functions, modalities, and the innovation role in the process of TESOL materials development. In 'The TESOL Encyclopedia of English Language Teaching', the practice of developing local materials, pronunciation and CALL (Computer-Assisted Language Learning) materials had been presented clearly in different styles (Hanson-Smith, 2018; Jones, 2018; Savova, 2018).

Liz England (2019b) provided a theoretical foundation of materials development in the edited book-TESOL Career Path Development, which represented model milestones of career path development to TESOL community. There were more thoughts and suggestions offered for both teachers and learners, such as more advocacies, systematic effort and professional developing materials (England, 2019a). Luis Carabantes (2019) focused on the research of materials developing innovation. They gave a review in the book named Creativity and Innovations in ELT Materials Development: Looking Beyond the Current Design. There was a survey report (Botifar, Boeriswati, \& Mayuni, 2019) that listed many Rejang language concepts in the Proceedings of the International Conference on Education. At the same time, a topic of addressing materials in the teachers' Continuing Professional Development (CPD) has been discussed in The Routledge Handbook of English Language Teacher Education (Graves \& Garton, 2019).

As regards the field of materials development, Brian Tomlinson (2020), is concerned with the issue of whether materials development is progressing. He predicted that the users (especially language learners) might "design, use and reflect on their own materials at the same time individually or in groups" (Tomlinson, 2020, p. 5). In honor of his contribution to the materials development research, the Language Teaching Research Quarterly had published a special issue (Volume 15) named 'Future perspectives and challenges of materials development' (Coombe \& Mohebbi, 2020). Marlyse Baptista (2020) published two online appendices of supplemental materials such as congruence across twenty languages and nineteen grammatical domains on the internet. Sayed Ahmad Al-Mousawi (2020) put forward a method of text-driven framework to develop the materials development activities. There was a research 
on deaf adults and children's late language exposure on spatial language development (Karadöller Sü mer \& O’ zyürek 2020). Junwei Niu and Mogana Dhamotharan $(2018,2020)$ also presented certain corpus-based medical learning materials for promoting the participant third-year medical students' creativity of materials development.

\section{Methodology}

\subsection{Validation Framework}

It is necessary to evaluate the validity and reliability of the ECBES before it is being implemented. The product form is a booklet, which is an exemplar of the ECBES of Unit Five 'Stress and Disease'. Inter-rater reliability and cross-check validation had been used to assess supplementary materials. The rate of the valid ECBES should be at least 70\% of agreement (Hallgren, 2012), which represents the reviewers' (including both teacher and student) beliefs and philosophical assumptions. Other items like the teacher's lesson plan checklist, observation tool, and classroom observation tool had been considered to certify the validity and reliability of the instructions.

\subsection{Instrument Development}

Different instruments were used to collect and analyze both the quantitative and qualitative data in this study. A questionnaire, observation, as well as semi-structured interviews have been used to collect practical data from the participant students and teachers. In the concrete process of collecting the ECBES practice data, the instrument used was the semi-structured interview. One-to-one interviews had been used to collect details of the teachers' practice experience and views. A focus group interview had been used to collect the students' participation experience and views. Uniform or parallel questions had been put forward in a friendly atmosphere during each interview, ensuring validity and reliability. Workshops were extracurricular activities to train the participant teachers and the 180 participant students to enrich or evaluate the hands-on ECBES. A WeChat Subscription Account called 'CBA4ME' — which means 'Corpus-Based Approach for Medical English'—was also used as a training and delivery platform to deliver the supplementary materials inside and outside the classroom.

\subsection{Participants and Data Collection}

The direct participants mainly focused on are the ME course teachers. Four teachers are teaching the ME course at the medical University. Purposive sampling had been used in the selection of the four teachers, based on the possibility of the research and the willingness of the teachers to participate. The demographic information of the participant teachers includes such items as sex, age, experience, qualifications such as degrees or special qualification in English language teaching (ELT). The study also involves indirect participants, such as third-year medical students. As one type of probability sampling, cluster sampling had been used for the selection of the 180 students. Clustering units of six classes, each class having 30 students had been selected for enhancing the sampling accuracy.

Both quantitative and qualitative data had been collected and analyzed separately by using mixed methods. It offered a variety of information and the participants' comprehensive views. The core notion of such a design is that the same concept had been used in both data collection processes (Creswell, 2014). Proper corpus tools (for example, AntConc, TagAnt, Laurence Anthony's web (Anthony, 2017): (http://www.laurenceanthony.net/software.html) and web-based corpora were widely used in the classroom. Web-based resources such as COCA (Corpus of Contemporary American English: https://www.english-corpora.org/coca/), and the most commonly used online corpora and corpus-based resources (https://www.english-corpora.org) have been used in the practice.

\subsection{Data Analysis}

Both quantitative and qualitative collected data could be analyzed and presented. Both descriptive and inferential analysis was chosen in this study. The "quantitative statistical data" (Creswell, 2014, p. 222) had been reported firstly. Then the qualitative findings had been discussed, which might converge or diverge on the quantitative statistical data. Lastly, the work of interpretation had been done to resolve the convergent or divergent issues in the comparative findings.

Furthermore, qualitative analysis has been used to analyze the collected textual, visual, and audio data, all of which would "cover a spectrum from confirmation to exploration" (Mihas, 2019). The qualitative data analysis has been directed by the theoretical and conceptual framework of this study. An inductive process has been carried out or driven by the qualitative data itself. Generic or basic qualitative analysis has also been used to solve the problem of lacking native-speaker ESP learning context, effect the change of developing ECBES, as well as identify relevant 
practical themes in the process of implementing ECBES.

\section{Results}

According to Tomlinson (2011a) and SLA-based principles for the ECBES materials development, there are several principles that should be adapted in the process of implementing an ECBES. For example, there were several factors considered in the developmental stages of this study, such as "motivation, engagement, cognitive challenge, rich samples of language input in authentic use, opportunities for meaningful language use, and focus on judiciously selected language structures encountered in input and output” (Mishan \& Timmis, 2015, p. 30).

Meanwhile, an effective corpus-based supplement had been developed which adapted the following principles: (1) Guiding students to focus on using language rather than just learning more about structure; students learn to use the appropriate language they need for communicating in real life; (2) Letting dynamic, supplementary function work well as an effective corpus-based supplement, which could give the students opportunities for a thorough and meaningful rehearsal of the Medical English (ME) course that they need for effective communication; (3) Emphasizing on developing skills of medical discourse within a wide range of communicative settings. It had actively trained the learner in important discourse functions, which should be presented in real-life contexts and related to the students' own experience.

The main procedures of the ECBES materials development in this study involve eight stages. They are:

(1) Enriching the selected unit in the textbook in current use with relevant corpora for teaching English to the third-year medical students in their fifth semester at Xinxiang Medical University China.

(2) Training the participant teachers through the one-by-one collaborative corpus workshops.

(3) Channeling the ECBES (both materials and activities) to the teachers and third-year medical students.

(4) Implementing the ECBES in the Medical English (ME) course.

(5) Collecting and analyzing the collected data.

(6) Evaluating the feedback of both teachers and students and the effects of using the ECBES in the process of teaching and learning.

(7) Refining the ECBES based on the feedback of teachers and students.

(8) Recommending the ECBES as a part of CPD training to teachers teaching English to the medical students.

The basic elements of the Foreign or Second Language Teaching (FLT/SLT) for the ECBES practice were a "structural syllabus and wordlist" (Richards \& Rodgers, 2014, p. 49). In general, the procedures of course design could be listed as needs-analysis, goals and objectives, syllabus design, methodology, and materials selection, and testing and evaluation. Furthermore, another model of course design procedures in practice, including material users and producers, the general framework of the class learners/goals could be created by material users. In contrast, materials selection could be made by material producers or developers, who could select the materials A, B, C, such as needs analysis, objectives, syllabus, and methodology (Masuhara, 2011; Tomlinson, 2011a).

Also, there are several principles that should be followed in the process of designing materials and activities. The supplementary materials that genuinely help supplement the textbook and improve ESP language proficiency involve problem-solving, learner-centered, and genuinely cross-curricular, and are based on the proper and latest SLA research. All of these principles should be clearly examined for specified purposes and contexts, which could be summed up as the analysis of "materials-in-action” (Littlejohn, 2011, p. 181).

In the process of designing the ECBES materials and activities, there is "a preliminary framework for materials analysis, evaluation, and action" (Littlejohn, 2011, p. 212) in practice, such as the analysis of the target situation of the ECBES use. For example, the process should include analyzing the cultural context, the institution, the Medical English (ME) course including the proposed aims, contents, methodology and means of evaluation, the participant teachers, the learners, and the materials analysis. It should primarily emphasize the procedures from the ECBES analysis to its description. It should deal with the explicit nature, requirement of users, and the implication of their use to the design and implementation. It should also involve matching and evaluating, for example, the appropriation of design and the target situation of use. The last step is action, which includes the rejection, adaption, and supplementation of the materials, or making the materials a critical object.

Meanwhile, in designing the ECBES, two issues were considered: Was there a strong theoretical affiliation between the supplementary materials and pedagogy? Were the overall detailed data obtained different from the subjectively selected ones which were "either weakly stated or absent"? (John David Bunting, 2013, p. 18). From the process of enriching the exemplar above, it can be concluded that there were seven concrete stages for enriching 
corpus-based materials, as shown in Table 1. Based on these stages, the study had taken ten steps to integrate a corpus-based supplement into a language teaching practice.

The evaluation of the ECBES had been done "between pre-use, whilst-use and post-use" (Mishan \& Timmis, 2015, p. 59) with the help of some corpus and language teaching experts, participant teachers as well as the 180 third-year medical students at Xinxiang Medical University (XXMU). The whilst-use evaluation should focus on many aspects. Like "clarity of instructions, layout, comprehensibility, credibility, achievability of tasks, the achievement of performance objectives, the potential for localization, practicality, teachability, flexibility, appeal, motivating power, impact, and effectiveness in facilitating short-term learning” (Tomlinson, 2003c, p. 24). After its evaluation, another step had been taken to modify the ECBES, based on the positive or negative comments of the corpus-based pedagogic activities (Bell \& Gower, 2011).

Table 1. The Concrete Stages for Enriching Corpus-Based Materials

\begin{tabular}{|c|c|c|c|}
\hline Stages & Agent & Investigation & Methods \\
\hline Planning & $\begin{array}{l}\text { The researcher } \\
\text { The participant teachers }\end{array}$ & Needs analysis & $\begin{array}{c}\text { Questionnaires } \\
\text { Interviews } \\
\text { Classroom Observation }\end{array}$ \\
\hline Drafting & The researcher & Literature review & Reflection \\
\hline Evaluation & Reviewers selected by the researcher & Reading of the materials & Criterion-Referenced Evaluation \\
\hline Piloting & $\begin{array}{l}\text { The participant teachers } \\
\text { The participant students }\end{array}$ & Trialing & $\begin{array}{c}\text { Questionnaires } \\
\text { Interviews } \\
\text { Classroom Observation Testing }\end{array}$ \\
\hline Enrichment & $\begin{array}{l}\text { The researcher } \\
\text { The participant teacher } \\
\text { The participant students }\end{array}$ & Consultation & The Corpus-Based Approach (CBA) \\
\hline Refining & $\begin{array}{l}\text { The researcher } \\
\text { The participant teachers } \\
\text { The participant students }\end{array}$ & Feedback & The CBA \\
\hline Post-Enrichment & $\begin{array}{c}\text { Reviewers } \\
\text { The researcher } \\
\text { The participant teachers }\end{array}$ & Recommending and using record & $\begin{array}{c}\text { Evaluation } \\
\text { Analyzing Data }\end{array}$ \\
\hline
\end{tabular}

Note: The detailed enriching stages. Adapted from What do teachers want from coursebooks? (p. 254) In B. Tomlinson (Ed.), Materials development in language teaching ( $2^{\text {nd }}$ ed., pp. 236-266), by Masuhara, 2011, Cambridge: Cambridge University Press. Copyright 2011 by Cambridge University Press. Adapted with permission.

\section{Discussion}

\subsection{Discussion of 'Reasoning Sense'}

Observation subject: 3P2 (Code of a participant's name, similarly hereinafter) from the $3^{\text {rd }}$ focus group students

As one of the most important skills for the cognitive science of reasoning, reasoning sense is very important in materials development. In this case, many ways in which it can be related to human reasoning sense have been tried to explore a computational-level ESP supplementary materials development and implementation (Oaksford \& Chater, 2002).

\subsection{Discussion on 'Enriching Supplementary Function of the ECBES'}

Observation subject: 3P2 from the $3^{\text {rd }}$ focus group of students

In this part of discussion on 'enriching supplementary function of the ECBES', certain supplementing observation data with additional information from 3P2 in the $3^{\text {rd }}$ focus group of students have been collected. Thus, the supplementary qualitative data have served the dual role of providing adjustments to the implementation for consistencies and also refining the ECBES for improved developing and implementing efficiency (Leung, Yamada, \& Zhang, 2005). 


\subsection{Discussion on 'Enriching the Source of Corpus-Based Translation Examples'}

Observation subject: 3P4 from the $3^{\text {rd }}$ focus group of students

In this part, it is clear that the Corpus-Based Approach (CBA) has the advantage of enriching the source of corpus-based translation examples. From the view of Sofia Malamatidou (2017), corpus-based supplement would benefit from the triangulation of corpora in the aspect of "actually employing combined corpus data and methods in the field” (Malamatidou, 2017, p. 8).

\subsection{Discussion on 'The Issue of Limited Use of the ECBES'}

Observation subject: 3P6, 3P5 from the $3^{\text {rd }}$ focus group of students

In this part of discussing the issue of limited use of the ECBES, one of the participant teachers, Mr Zhang though that the corpus is not all powerful in materials development. The limit use of the ECBES may focus on the "gap between the presentation of grammar rules in the selected ESL/EFL books" (Chalabian, 2020, p. 82) and the real use of ESP medical literature.

\subsection{Discussion on 'A Sufficient and Rich Exposure'}

According to the view of the Native Speakers (NSs), English learners would like to get native-speaker-like fluency because of their ultimate attempt to acquire NSs' standards through the exposure stimulus (Lee, 2012). Through the observation of the focus group students, some questions had been raised and solved via observing their behaviors in the ECBES activities. 2P11 had said that the ECBES was not particularly close to their real lives. As to their actual use, did they have concrete ideas or suggestions for developing ECBES so that it became closer to the students' lives? The researcher had doubted whether the ECBES had provided sufficient and rich exposure to the students with authentic Medical English (ME) language data. As it was a descriptive question, they had talked of their emotional feelings. As for the native language, it had focused on the native speaker. The ECBES materials might be different after processing them so often, and the ultimate materials shown to everyone were something that changed so much. In other words, it could not be considered the original text message.

More than $60 \%$ of the students thought that they had a sufficient and rich exposure. It had focused on being local, and close to the language of the native speaker, providing authentic Medical English (ME) language data.

(1) They had been fully exposed to the authentic language data. It had reflected the benefits of being exposed to authentic language materials but posed difficulties in learning professional terms and materials. 2P2 felt that she was fully exposed to authentic Medical English (ME) data abroad in checking words, phrases, usage, and some fixed expression while writing papers. They were all from authentic foreign papers. $2 \mathrm{P} 5$ said that even though they were fully exposed to the native-speaker and authentic ME language data, the difficulty of understanding relatively professional medical materials existed because they were fresh for the ME course. 2P11 had experienced sufficient and rich exposure as she was willing to contact and learn. She had experienced ECBES's sufficient, rich exposure to Native Speakers' (NSs) authentic ME information. She was willing to use the ECBES materials, which had been found in the authentic foreign medical literature. They all were important to the medical students, though the translation might not be accurate or might have undergone some changes because of the translation. 2P14 stated that they had been provided sufficient, rich exposure and focusing on both Chinese meaning and contextual interpretation was helpful to understand. She thought that they could focus on both the Chinese explanation and the interpretation of the English context. She felt that the ECBES would provide sufficient, rich exposure to them. NSs' authentic ME information helped understand difficult words and fixed sentence patterns.

(2) Informative corpora provided sufficient, rich exposure. 2P6 thought that the corpora were very informative. They could offer adequate exposure such as authentic ME language data if not now but in the future.

(3) It was the constant use that made it possible to touch authentic materials as the original examples and sources. 2P3 felt that the examples and sources of the ECBES were very original. He indicated that it depended on the possibility of touching the NSs' authentic Medical English (ME) information.

(4) It was useful to understand the real context reflected in the authentic example sentences. 2P10 realized that the important words, fixed sentences, literary expressions of these Native Speakers' (NSs) and authentic data were useful to understand the information and meanings from real context.

(5) It had accessed the Native Speakers (NSs) and the authentic ME language data. 2P13 indicated that she had accessed the language of the native-speaker and the authentic ME language data in the ECBES practice. She thought language learning was a gradual process and mastering the Corpus-Based Approach (CBA) could facilitate learning 
more related data.

(6) It had been suggested that students got exposed to more movies and literature. 2P9 thought that ECBES had not provided sufficient, rich exposure to him. As the corpus was a tool for learning, he suggested watching some movies or reading some ME literature to get exposed to the language data of the native speaker.

From the students' views about the exposure stimulus, it could be found that there was a new way of learning ME "ranging from fairly formal or at least self-monitored speech (as in interviews) to casual, spontaneous chatter" (Halliday, 2004, pp. 34-35). With the advantages of "huge authentic data, accurate and fast extraction" (He, 2004, p. 26), one can handle the exposure stimulus. The ECBES practice was a benefit to the transfer of the teaching and learning processes from traditional teacher-centered and knowledge cramming to the learner-centered and skill exploring.

The practice of the ECBES had emphasized the need for additional class teaching to be organized around "authentic and meaningful" (Richards \& Rodgers, 2014, p. 101) uses of ME that linked to the personal needs of the third-year medical students. Through the additional class, those needs were realized through many corpus-based activities. They had involved text-based KWICs negotiation of meaning, NSs' natural verbal data, and supplementary materials development. All of these activities had facilitated the exposure stimulus of the participant teachers.

The exposure stimulus had benefited both the teachers and their student participants. It had reflected in several ways: (1) Comparing the verbal usage of Native Speakers' (NSs), they could understand the features of the language use of the Non-native Speakers (NNSs) in ME teaching. (2) To a certain degree, the NNSs' mother tongue affects their ME learning behavior. (3) Under certain conditions, the NNSs took the avoidance strategy, making them avoid the chance to use the ME comprehensively and frequently. (4) The ME learning behavior was close to the NSs' learning behaviors. (5) Some procedures and steps could narrow or bridge the gap between NNSs and NSs (Zhang, 2004).

In sum, this case study has reported the corpus-based materials development research and argued that the corpus-based materials developing stages deserved more attention in the whole process of teaching and learning. The participants' comments regarding the functions of corpus-based supplementary materials and activities as a supplement in learning the ESP language skills were analyzed and juxtaposed with the observation data for participants. The significance of this study are multi-aspects: Enriching medical teaching materials; promoting participants' teaching and learning efficiency, quality, and enhancing the relationship between teachers and students; as well as diversifying the Medical English pedagogy. Results indicated that a well-arranged, concise, and convenient ECBES is very useful for both teachers and students. They had benefitted from the pedagogical implications of using the ECBES in-class and in their daily learning life.

\section{References}

Ableeva, R. and Stranks, J. (2013). Listening in another language-research and materials. In B. Tomlinson (Ed.), Applied Linguistics and Materials Development (pp. 199-212). London: Bloomsbury Academic.

Al-Busaidi, S. and Tindle, K. (2010). Evaluating the impact of in-house materials on language learning. In B. Tomlinson \& H. Masuhara (Eds.), Research for Materials Development in Language Learning: Evidence for Best Practice (pp. 137-149). London: Bloomsbury Academic.

Al-Mousawi, S. A. (2020). English language materials development: Text-driven framework as an approach. English Language Teaching, 13(11), 40-48. doi: https://doi.org/10.5539/elt.v13n11p40.

Andon, N. (2018). Materials development for TESOL. ELT Journal, 72(1), 112-113. doi: https://doi.org/10.1093/ elt/ccx062.

Anthony, L. (2017). AntConc software. Retrieved from http://www.laurenceanthony.net/software.html.

Bailey, K. M. and Masuhara, H. (2013). Language testing washback: The role of materials. In B. Tomlinson (Ed.), Applied Linguistics and Materials Development (pp. 303-318). London: Bloomsbury Academic.

Bale, R. (2013). Spoken corpus-based resources for undergraduate initial interpreter training and lexical knowledge acquisition: Empirical case studies. (Doctor of Philosophy), University of Surrey, (27557462).

Baptista, M. (2020). Competition, selection, and the role of congruence in Creole genesis and development. Linguistic Society of America, 96(1), 160-199. doi: https://doi.org/10.1353/lan.2020.0016.

Bardovi-Harlig, K. and Mossman, S. (2016). Corpus-based materials development for teaching and learning pragmatic routines. In B. Tomlinson (Ed.), SLA Research and Materials Development for Language Learning (pp. 266-283). New York: Routledge. 
Bell, J. and Gower, R. (2011). Writing course materials for the world: A great compromise. In B. Tomlinson (Ed.), Materials development in language teaching ( $2^{\text {nd }}$ ed., pp. 135-150). Cambridge: Cambridge University Press.

Botifar, M., Boeriswati, E., and Mayuni, I. (2019). Descriptive analysis of syllabus and Rejang language teaching materials: Preliminary study development of local language teaching. Paper presented at the Proceedings of the International Conference on Education, Jakarta.

Bunting, J. D. (2013). An investigation of language teachers' explorations of the use of corpus tools in the English for academic purposes (EAP) class. (Doctor of Philosophy), Georgia State University, Georgia. (3591056)

Bunting, J. D. (2018). Second language writing materials development. The TESOL Encyclopedia of English Language Teaching, 1-6. doi: https://doi.org/10.1002/9781118784235.eelt0547.

Burns, A. and Hill, D. A. (2013). Teaching speaking in a second language. In B. Tomlinson (Ed.), Applied Linguistics and Materials Development (pp. 231-248). London: Bloomsbury Academic.

Canniveng, C. and Martinez, M. (2003). Materials development and teacher training. In B. Tomlinson (Ed.), Developing Materials for Language Teaching (pp. 479-489). London: Bloomsbury Academic.

Carabantes, L. (2019). Creativity and innovations in ELT materials development: Looking beyond the current design. TESOL Quarterly, 53(1), 281-283. doi: https://doi.org/10.1002/tesq.496.

Chai, N., Wannaruk, A., and Lian, A. (2015). A Corpus-based Study on Chinese EFL Learners' Use of Transitive Constructions with Neutral Participants. Theory and Practice in Language Studies, 5(9), 1778-1790. doi: https://doi.org/ 10.17507/tpls.0509.03.

Chalabian, F. (2020). ESL textbooks materials and real language use: Comparing corpus-based materials and textbook materials on gerunds/ infinitives. (Applied Linguistics and Discourse Studies), Carleton University, Ottawa, Ontario.

Cheung, C. L. (2014). Application of scaffolds in genre-informed approach to second language (L2) writing instruction: A case-study of EFL students with low proficiency. (Doctor of Education), The Chinese University of Hong Kong, Hong Kong. (3714841)

Coombe, C. and Mohebbi, H. (2020). Future perspectives and challenges of materials development: In honor of Brian Tomlinson's contribution to materials development research. Language Teaching Research Quarterly, 15, I-IV.

Creswell, J. W. (2014). Research design: Qualitative, quantitative, and mixed methods approaches (4th ed.). London: SAGE Pubications, Inc.

Cullen, B. (2010). Learning materials for L2 songwriters. In B. Tomlinson \& H. Masuhara (Eds.), Research for Materials Development in Language Learning: Evidence for Best Practice (pp. 189-206). London: Bloomsbury Academic.

Darici, A. and Tomlinson, B. (2016). A case study of principled materials in action. In B. Tomlinson (Ed.), SLA Research and Materials Development for Language Learning (pp. 87-102). New York: Routledge.

Edwin Ko, B. A. (2016). A corpus-based study of variation and change in adverb placement across world English. (Master of Science in Linguistics), Georgetown University, Washington, DC. (10102744)

Ellis, R. (2016). Language Teaching Materials as Work Plans: An SLA Perspective. In B. Tomlinson (Ed.), SLA Research and Materials Development for Language Learning (pp. 219-234). New York: Routledge.

England, L. (2019a). It's on us: Intentional TESOL career path Development. In L. England (Ed.), TESOL Career Path Development (pp. 104-111). New York: Routledge.

England, L. (2019b). Theorizing TESOL career path development. In L. England (Ed.), TESOL Career Path Development (pp. 11-29). New York: Routledge.

Fenton-Smith. (2013). The application of discourse analysis to materials design for language teaching. In B. Tomlinson (Ed.), Applied Linguistics and Materials Development (pp. 127-142). London: Bloomsbury Academic.

Flowerdew, L. (2015). Corpus-based research and pedagogy in EAP: From lexis to genre. Language Teaching, 48(1), 99-116. doi: https://doi.org/10.1017/S0261444813000037.

Fox, J. (1978). TELEFUN: A pragmatic approach to functional learning materials development. TESOL Quarterly, 12(3), 297-309. doi:https://doi.org/10.2307/3586056

Ghosn, I.-K. (2013). Language learning for young learners. In B. Tomlinson (Ed.), Applied Linguistics and Materials Development (pp. 61-74). London: Bloomsbury Academic. 
Graves, K. (2019). Recent books on language materials development and analysis. ELT Journal, 73(3), 337-354. doi:https://doi.org/10.1093/elt/ccz026.

Graves, K. and Garton, S. (2019). Materials use and development. In S. Walsh \& S. Mann (Eds.), The Routledge Handbook of English Language Teacher Education (pp. 417-431). London: Routledge.

Hallgren, K. A. (2012). Computing Inter-Rater Reliability for Observational Data: An Overview and Tutorial. Tutor Quant Methods Psychol, 8(1), 23-24. doi:https://doi.org/10.20982/tqmp.08.1.p023.

Halliday, M. A. K. (2004). An introduction to functional grammar ( $3^{\text {rd }}$ ed.). London: Routledge.

Hann, N. (2010). ESOL for employability training materials in the United Kingdom: Contexts and effects. In B. Tomlinson \& H. Masuhara (Eds.), Research for Materials Development in Language Learning: Evidence for Best Practice (pp. 172-188). London: Bloomsbury Academic.

Hanson-Smith, E. (2018). CALL (Computer-Assisted Language Learning) materials development. The TESOL Encyclopedia of English Language Teaching, 1-7. doi: https://doi.org/10.1002/9781118784235.eelt0401.

Hartman, P. L. and Judd, E. L. (1978). Sexism and TESOL materials. TESOL Quarterly, 12(4), 383-393. doi:https://doi.org/10.2307/3586137

He, A. (2004). Corpora and foreign language teaching. In A. He (Ed.), Application of corpora to foreign language education: Theory and practice (pp. 23-30). Guangzhou: Guangdong Higher Education Press.

Imhoof, M. (1968). Controlling cultural variations in the preparation of TESOL materials. TESOL Quarterly, 2(1), 39-42. doi:https://doi.org/10.2307/3585441.

Jones, T. (2018). Materials development for teaching pronunciation. The TESOL Encyclopedia of English Language Teaching, 1-7. doi:https://doi.org/10.1002/9781118784235.eelt0697.

Karadöller D. Z., Sü mer B., and Ơ zyürek A. (2020). Effects and non-effects of late language exposure on spatial language development: Evidence from deaf adults and children. Language Learning and Development, 1-25. Retrieved from doi: https://doi.org/10.1080/15475441.2020.1823846.

Kennedy, C. and Tomlinson, B. (2013). Implementing language policy and planning through materials development. In B. Tomlinson (Ed.), Applied Linguistics and Materials Development (pp. 255-268). London: Bloomsbury Academic.

Lee, J. H. (2012). Implications for language diversity in instruction in the context of target language classrooms: Development of a preliminary model of the effectiveness of teacher code-switching. English Teaching: Practice and Critique, 11(4), 137-160. Retrieved from https://files.eric.ed.gov/fulltext/EJ999769.pdf.

Leung, D. H. Y., Yamada, K., and Zhang, B. (2005). Enriching surveys with supplementary data and its application to studying wage regression. Scandinavian Journal of Statistics, 42(1), 155-179. doi: https://doi.org/10.1111/ sjos.12100.

Levy, M. (1994). Forum CALL materials development survey report. Computer Assisted Language Learning, 7(2), 175-189. doi: https://doi.org/10.1080/0958822940070208.

Littlejohn, A. (2011). The analysis of language teaching materials: Inside the Trojan Horse. In B. Tomlinson (Ed.), Materials development in language teaching ( $2^{\text {nd }}$ ed., pp. 179-211). Cambridge: Cambridge University Press.

Lutzker, P. (2013). Beyond semantics: Moving language in foreign language learning. In B. Tomlinson (Ed.), Applied Linguistics and Materials Development (pp. 31-42). London: Bloomsbury Academic.

Lyons, P. (2003). A practical experience of institutional textbook writing: Product/Process implications for materials development. In B. Tomlinson (Ed.), Developing Materials for Language Teaching (pp. 490-594). London: Bloomsbury Academic.

Mackey, A., Ziegler, N., and Bryfonski, L. (2016). From SLA research on interaction to TBLT materials. In B. Tomlinson (Ed.), SLA Research and Materials Development for Language Learning (pp. 119-134). New York: Routledge.

Malamatidou, S. (2017). Triangulation in corpus-based translation studies. In S. Malamatidou (Ed.), Corpus Triangulation: Combining Data and Methods in Corpus-Based Translation Studies (pp. 8-23). London: Routledge.

Masuhara, H. (2011). What do teachers really want from coursebooks? In B. Tomlinson (Ed.), Materials development in language teaching $\left(2^{\text {nd }}\right.$ ed., pp. 236-266). Cambridge: Cambridge University Press.

Masuhara, H. (2016). Brain studies and materials for language learning. In B. Tomlinson (Ed.), SLA Research and Materials Development for Language Learning (pp. 39-48). New York: Routledge.

Masuhara, H. and Tomlinson, B. (2010). Applications of the research results for materials development. In B. Tomlinson 
\& H. Masuhara (Eds.), Research for Materials Development in Language Learning: Evidence for Best Practice (pp. 410-424). London: Bloomsbury Academic.

Mihas, P. (2019). Qualitative Data Analysis. Oxford Research Encyclopedia of Education. doi: https://doi.org/10.1093/ acrefore/9780190264093.013.1195.

Mishan, F. (2010). Withstanding washback: Thinking outside the box in materials development. In B. Tomlinson \& H. Masuhara (Eds.), Research for Materials Development in Language Learning: Evidence for Best Practice (pp. 353-368). London: Bloomsbury Academic.

Mishan, F. (2016). Comprehensibility and cognitive challenge in language learning materials. In B. Tomlinson (Ed.), SLA Research and Materials Development for Language Learning (pp. 182-200). New York: Routledge.

Mishan, F., and Timmis, I. (2015). Materials development for TESOL. Edinburgh: Edinburgh University Press Ltd.

Nakata, T. and Webb, S. (2016). Vocabulary learning exercises: Evaluating a selection of exercises commonly featured in language learning materials. In B. Tomlinson (Ed.), SLA Research and Materials Development for Language Learning (pp. 139-154). New York: Routledge.

Niu, J. and Dhamotharan, M. (2020). Developing medical learning materials to promote learners' creativity: A corpus-based case study. Arab World English Journal, 11(4), 181-193. doi: https://dx.doi.org/ 10.24093/awej/vol11no4.12.

Oaksford, M. and Chater, N. (2002). Commonsense reasoning, logic, and human rationality. In R. Elio (Ed.), Common Sense, Reasoning, and Rationality (pp. 174-214): Oxford Scholarship Online.

Paltridge, B. and Starfield, S. (2012). The Handbook of English for Specific Purposes. New York: John Wiley \& Sons, Inc.

Paltridge, B. and Starfield, S. (2017). English for Specific Purposes. In E. Hinkel (Ed.), Handbook of Research in Second Languge Teaching and Learning (Vol. 3, pp. 56-67). New York: Routledge.

Pryor, S. (2010). The development and trialling of materials for second language instruction: A case study. In B. Tomlinson \& H. Masuhara (Eds.), Research for Materials Development in Language Learning: Evidence for Best Practice (pp. 207-223). London: Bloomsbury Academic.

Reinders, H. (2011). Materials development for learning beyond the classroom. In P. Benson \& H. Reinders (Eds.), Beyond the Language Classroom (pp. 175-189). London: Palgrave Macmillan.

Reinders, H. and Pegrum, M. (2016). Supporting language learning on the move: An evaluative framework for mobile language learning resources. In B. Tomlinson (Ed.), SLA Research and Materials Development for Language Learning (pp. 235-247). New York: Routledge.

Richards, J. C. and Rodgers, T. S. (2014). Approaches and Methods in Language Teaching (3 ${ }^{\text {rd }}$ ed.). Cambridge: Cambridge University Press.

Savova, L. (2018). Local materials development practices. The TESOL Encyclopedia of English Language Teaching, 1-13. doi: https://doi.org/10.1002/9781118784235.eelt0720.

Shin, J. K. (2016). Building a sustainable community of inquiry through online TESOL professional development. In L. England (Ed.), TESOL Career Path Development (pp. 143-160). New York: Routledge.

Starfield, S. (2014). Current and future directions in English for Specific Purposes research. Revue française de linguistique appliquée, XIX(1), 9-14. doi:https://doi.org/10.3917/rfla.191.0009.

Stillwell, C., Kidd, A., Alexander, K., McIlroy, T., Roloff, J., and Stone, P. (2010). Mutual benefits of feedback on materials through collaborative materials evaluation. In B. Tomlinson \& H. Masuhara (Eds.), Research for Materials Development in Language Learning: Evidence for Best Practice (pp. 257-272). London: Bloomsbury Academic.

Stillwell, C., McMillan, B., Gillies, H., and Waller, T. (2010). Four teachers looking for a lesson: Developing materials with lesson study. In B. Tomlinson \& H. Masuhara (Eds.), Research for Materials Development in Language Learning: Evidence for Best Practice (pp. 237-250). London: Bloomsbury Academic.

Storjohann, P. (2005). Corpus-driven vs. corpus-based approach to the study of relational patterns. Paper presented at the Corpus Linguistics 2005 conference, Birmingham.

Timmis, I. (2013). Spoken language research: The applied linguistic challenge. In B. Tomlinson (Ed.), Applied Linguistics and Materials Development (pp. 79-94). London: Bloomsbury Academic. 
Tomlinson, B. (2003a). Developing principled frameworks for materials development. In B. Tomlinson (Ed.), Developing Materials for Language Teaching (pp. 107-129). London: Bloomsbury Academic.

Tomlinson, B. (2003b). Introduction: Are materials developing? In B. Tomlinson (Ed.), Developing Materials for Language Teaching ( $2^{\text {nd }}$ ed., pp. 1-17). London: Bloomsbury Publishing Plc.

Tomlinson, B. (2003c). Materials evaluation. In B. Tomlinson (Ed.), Developing materials for language teaching (pp. 15-36). London: Continuum.

Tomlinson, B. (2003d). Preface. In B. Tomlinson (Ed.), Developing Materials for Language Teaching (2nd ed., pp. ix-xi). London: Bloomsbury Publishing Plc.

Tomlinson, B. (2011a). Developing materials for language teaching ( ${ }^{\text {nd }}$ ed.). London: Continuum International Publishing Group.

Tomlinson, B. (2011b). Introduction: Principles and procedures of materials development. In B. Tomlinson (Ed.), Materials development in language teaching $\left(2^{\text {nd }}\right.$ ed., pp. 1-31). Cambridge: Cambridge University Press.

Tomlinson, B. (2012). Materials development for language learning and teaching. Language Teaching, 45(2), 143-179. doi:https://doi.org/10.1017/S0261444811000528.

Tomlinson, B. (2013a). Classroom research of language classes. In B. Tomlinson (Ed.), Applied Linguistics and Materials Development (pp. 43-60). London: Bloomsbury Academic.

Tomlinson, B. (2013b). Innovation in materials development. In K. Hyland \& L. L. C. Wong (Eds.), Innovation and Change in English Language Education (pp. 219-233). London: Routledge.

Tomlinson, B. (2013c). Second language acquisition and materials development. In B. Tomlinson (Ed.), Applied Linguistics and Materials Development (pp. 11-30). London: Bloomsbury Academic.

Tomlinson, B. (2016a). Achieving a match between SLA theory and materials development. In B. Tomlinson (Ed.), SLA Research and Materials Development for Language Learning (pp. 19-38). New York: Routledge.

Tomlinson, B. (2016b). The importance of materials development for language learning. In M. Azarnoosh, M. Zeraatpishe, A. Faravani, \& H. R. Kargozari (Eds.), Issues in Materials Development (pp. 1-9). Netherlands: SensePublishers, Rotterdam.

Tomlinson, B. (2016c). PART II Materials driven by SLA theory. In B. Tomlinson (Ed.), SLA Research and Materials Development for Language Learning (pp. 85-86). New York: Routledge.

Tomlinson, B. (2020). Is materials development progressing? Language Teaching Research Quarterly, 15, 1-20. doi:https://doi.org/10.32038/ltrq.2020.15.01.

Tomlinson, B. and Masuhara, H. (2003). Simulations in materials development. In B. Tomlinson (Ed.), Developing Materials for Language Teaching (pp. 462-478). London: Bloomsbury Academic.

Tomlinson, B. and Masuhara, H. (2010). Published research on materials development for language learning. In B. Tomlinson \& H. Masuhara (Eds.), Research for Materials Development in Language Learning: Evidence for Best Practice (pp. 1-18). London: Bloomsbury Academic.

Trabelsi, S. (2010). Developing and trialling authentic materials for Business English students at a Tunisian University. In B. Tomlinson \& H. Masuhara (Eds.), Research for Materials Development in Language Learning: Evidence for Best Practice (pp. 103-120). London: Bloomsbury Academic.

Troncoso, C. R. (2010). The effects of language materials on the development of intercultural competence. In B. Tomlinson \& H. Masuhara (Eds.), Research for Materials Development in Language Learning: Evidence for Best Practice (pp. 83-102). London: Bloomsbury Academic.

Ullmann, R. (1990). Materials development as a professional development process. The Canadian Modern Language Review, 46(4), 714-722. doi: https://doi.org/10.3138/cmlr.46.4.714.

Wala, D. A. S. (2003). Publishing a coursebook: Completing the materials development Circle. In B. Tomlinson (Ed.), Developing Materials for Language Teaching (pp. 141-161). London: Bloomsbury Academic.

Yang, Q. (2014). A Corpus-based Study of Chinese English Learners' Use of Somewhat. Theory and Practice in Language Studies, 4(11), 2331-2336. doi: https://doi.org/10.4304/tpls.4.11.2331-2336.

Zhang, J. (2004). The review of using corpora for English language teaching. In A. He (Ed.), Application of corpora to foreign language education: Theory and practice (pp. 31-38). Guangzhou: Guangdong Higher Education Press. 